\title{
VI Congresso Internacional de Direito do Trabalho e da Segurança Social.
}

\author{
Relatório apresentado pelos Professôres \\ ANTônio Ferreira Cesarino Júnior Catedrá- \\ tico e Marly ANTONIETa Cardone, Assistente.
}

De 14 a 17 de agôsto de 1966, reuniu-se em Stockolmo, na Suécia, o VI Congresso Internacional de Direito do Trabalho e da Segurança Social. O certame foi promovido pela Sociedade Internacional de Direito do Trabalho e da Segurança Social, de que o primeiro dos relatores é Presidente Honorário.

A sIDTss tem por objetivo estudar, com finalidade científica, o Direito do Trabalho e o Direito da Segurança Social, tanto no plano nacional, como no internacional e permitir o intercâmbio de idéias e de informações, assim como uma colaboração tão estreita quanto possível entre todos os juristas que, nos diferentes países, se consagram ao estudo ou à aplicação daquela disciplina.

Realizou ela anteriormente cinco congressos internacionais, a saber: em Trieste (1951), São Paulo (1954), êste na Faculdade de Direito da Universidade de São Paulo, Genebra (1957), Bruxelas (1958) e Lyon (1963).

O VI Congresso teve a sua comissão científica composta de: Renato Balzarini (Itália), Marie-Louise Beaulieu (Canada), Alexandre Berenstein (Suíça), André Brun (França), Rafael Caldera (Venezuela), A. F. Cesarino Jr. (Brasil), Mário de la Cueva (México), Rolf Dietz (Alemanha), Paul André Horion (Bélgica), Masaichiro Ishizaki (Japão), L. A. Jaramillo Perez (Equador), C. Wilfred 
Jenks (B.I.T.), Otto Kahn-Freund (Grã-Bretanha), Harold A. Katz (Estados Unidos), Chi Sun Kim (Coréia), Marius G. Levenbach (Países Baixos), Renato Morelli (A.I.S.S.), José Montenegro Baca (Peru), Ladislaus Nagy (Hungria), Hans Carl Nipperdey (Alemanha), Eugenio Perez Botija (Espanha), Bochko K. Peritch (Iugoslávia), Ferit H. Saymen (Turquia), Folke Schmidt (Suécia), Ruy A. Sodré (Brasil), Clyde Summers (Estados Unidos), Antti Suviranta (Finlândia), Waclaw Szubert (Polônia), Mariano Rubin Tissembaum (Argentina), Igor Tomes (Tchecoslováquia), Fernand van Goethem (Bélgica) e Francisco Walker Linares (Chile). Integraram a sua comissão executiva: Otto Kahn Freund (Grã-Bretanha), Alexandre Berenstein (Suíça), Folke Schmidt (Suécia) e Harold A. Katz (Estados Unidos). Pertencem à comissão de organização: Folke Schmidt, Erik Forstadius, Axel Wallén e Rudolf Rajmic.

Compareceram ao Congresso cêrca de 500 especialistas de tôda a Europa, inclusive dos países chamados sociaIistas, das três Américas e de alguns países da África e da Ásia, tais como Índia, Japão e Coréa do Sul. Do Brasil compareceram, além dos relatores, o Prof. José Martins Catharino, da Baía e os Drs. Celso Barroso Leite e Luiz Paranhos Veloso, do Instituto de Aposentadoria e Pensões dos Industriários. Além do Prof. Catharino, foram relatores nacionais brasileiros o Prof. Célio Goyatá, de Belo Horizonte e o Dr. Wilson de Souza Campos Batalha, de São Paulo. O Prof. Ruy de Azevedo Sodré, Secretário Geral, designou tais relatores e desenvolveu intensa atividade no sentido de tornar conhecida a realização do Congresso e de para êle convidar os juslaboristas latino-americanos e especialmente brasileiros.

No primeiro dia, 14 de agôsto, houve a inscrição dos congressistas, no magnífico edifício da Folkets Hus (Casa do Povo), sita à Barnhusgatan, 12-14, no centro de Stockolmo, esplêndida sede comum de sindicatos, com amplas instalações, onde se realizaram tôdas as atividades científicas do Congresso. 
$\mathrm{Na}$ tarde dêsse mesmo dia, o Instituto Sueco para as Relações Culturais com o Estrangeiro ofereceu aos congressistas e as suas espôsas brilhante recepção, no Centro Wenner-Gren, situado em Sveavägen, 166 , no $23 .^{\circ}$ andar de um dos mais novos arranha-céus de Stockolmo. À noite, o Prof. Cesarino Júnior participou, com os demais membros das Comissões Científicas e de Organização do Congresso, de um jantar durante o qual foi aprovada a sua ordem do dia.

A abertura oficial dos trabalhos se deu no dia 15 pela manhã, tendo proferido os discursos inaugurais, o Ministro da Justiça, Dr. Herman Kling, pelo Govêrno Sueco; o Prof. Otto Kahn Freund, seu presidente, pela sidtss e o Dr. C. Wilfred Jenks, seu sub-Diretor, pela Organização Internacional do Trabalho. Foi aclamado Presidente do Congresso, o Prof. Folke Schmidt, de Stockolmo, homenageando-se, a memória do eminente Prof. Eugênio Perez Botija, da Espanha, falecido em junho.

Em seguida, sob a presidência do Prof. Kahn-Freund, da Universidade de Oxford, na Inglaterra, se realizou a primeira sessão de trabalho do Congresso. O Prof. Georges F. Rohrlich, de Chicago, nos Estados Unidos, apresentou o relatório geral sôbre o tema I: Problemas Jurídicos da Fixação das Prestações da Segurança Social, notadamente em função das modificações do custo de vida e dos salários. Seguiu-se a discussão, da qual participaram numerosos congressistas, a qual continuou no período da tarde, após um almôço oferecido pelo Ministro da Justiça aos dirigentes do Congresso.

À noite, houve, na magnificente Rathus (Casa da Câmara Municipal) de Stockolmo, uma recepção of erecida pelo seu Prefeito. Respondeu ao discurso dêste, em nome dos congressistas, o Prof. Cesarino Júnior.

A sessão do dia 16 foi presidida pelo Prof. Cesarino Iúnior. Foram relatores gerais os Profs. Folke Schmidt, de Stockolmo e Gino Giugni, de Roma, do Tema II: $A$ 
diferenciaçâo entre as diversas categorias de trabalhadores (trabalhadores manuais e não manuais, pessoal de vigilância, de direção, pessoal das funções públicas, etc.), tanto do ponto de vista da lei e das convenções coletivas, como da prática profissional, em geral. Foi êste o tema sôbre o qual se pronunciou o maior número de congressistas.

À noite, o Ministro da Justiça ofereceu esplêndida recepção aos congressistas, no edifício do Ministério dos Negócios Estrangeiros.

A última sessão de trabalho do Congresso se realizou na manhã do dia 15, sob a presidência do Prof. Alexandre Berenstein, de Genebra, Secretário Geral da sidsss. O Prof. Marcel David, de Paris, foi o relator geral do Tema III: O Estado atual do Direito do Trabalho e da Segurança Social no domínio do ensino e da pesquisa, assim como as relações desta disciplina com as ciências conexas, seguindo-se os debates, nos quais se destacaram as intervenções do Prof. André Brun, de Lyon e do Dr. Georges Spyropoulos, de Atenas.

À tarde, reuniu-se a sidTss em assembléia geral. Não aceitando o Prof. Kahn-Freund, Presidente e o Sr. Harold A. Katz, a sua reeleição, foram eleitos para êsses cargos os Profs. Folke Schmidt, da Suécia e Edwin Teple, dos Estados Unidos. Como secretários gerais foram confirmados os Profs. Alexandre Berenstein e Ruy Sodré.

À noite, a seção sueca da sidTss ofereceu, na Rathus, um suntuoso banquete de despedida aos congressistas, tendo discursado os Profs. Folke Schmidt e Kahn-Freund.

São Paulo, $10^{\circ}$ de setembro de 1966. 